\title{
МЕТОДОЛОГІЧНІ ПІДХОДИ ДО ПРОФЕСІЙНОГО СТАНОВЛЕННЯ МАЙБУТНІХ УЧИТЕЛІВ В УМОВАХ УНІВЕРСИТЕТСЬКОЇ ОСВІТИ
}

\author{
Осипова Т. Ю., Галіцан О. А.
}

\section{ВСТУП}

Реформування вищої освіти в Україні, пов'язане з входженням іiї в європейський освітній простір, висуває підвищені вимоги до професійної підготовки фахівців, готових до постійного саморозвитку, продуктивності, самореалізації в професійній діяльності. Зокрема, це стосується майбутніх учителів, професійна діяльність яких спрямована на виховання творчих, інтелектуально розвинених школярів, здатних до самоосвіти й самовиховання в подальшій життєдіяльності. Означене актуалізує проблему професійного становлення висококваліфікованих педагогів в умовах університетської освіти. Саме в період навчання в закладах вищої педагогічної освіти майбутні вчителі мають можливості для усвідомлення важливості педагогічної професії, розуміння своєї ролі в ній, оволодіти необхідними професійними знаннями, практичними вміннями та навичками, відповідно до обраної педагогічної спеціальності, адаптуватися до педагогічної діяльності, засвоїти правила й норми професійної етики та виробити власну позицію в подальшій професійній діяльності. Крім цього, професійне становлення майбутніх фахівців освітянської сфери передбачає також набуття важливих особистісних i професійних якостей, що сприятимуть виконанню професійних функцій у подальшій діяльності в закладах загальної середньої освіти.

Професійне становлення майбутніх учителів насамперед спрямоване на формування ідеального педагога національної школи, який, за визначенням науковців (І. Підласий, О. Савченко, С. Трипольська та ін.) повинен: 1) як фахівець - володіти знаннями педагогічної теорії та психології, педагогічною майстерністю, технологією навчання й виховання, уміннями раціонально організовувати пізнавальну діяльність учнів, любити дітей, вірити в людину; 2) як працівник - уміти поставити мету й домагатися ii виконання, розподіляти час, систематично підвищувати кваліфікацію, володіти здатністю до творчості, загальною ерудицією та обізнаністю, відзначатися розумним оптимізмом, помірним скептицизмом, бажанням працювати, відданістю справі й колективізмом; 
3) як людина - бути носієм високих моральних якостей, активним учасником громадського життя, мати активну життєву позицію, виявляти повагу до законів держави, у нього повинна бути сформована національна свідомість і самосвідомість, національна гідність, патріотизм, готовність до захисту батьківщини, гуманізм, духовність і релігійність ${ }^{1}$.

Варто зазначити, що різні аспекти професійного становлення майбутніх учителів були предметом наукових розвідок значної кількості дослідників: таких як О. Абдуліна, І. Богданова, А. Богуш, Л. Божович, С. Вершловський, А. Деркач, М. Свтух, Е. Карпова, Н. Кічук, Н. Кузьміна, 3. Курлянд, А. Линенко, А. Маркова, Л. Мітіна, I. Пальшкова, В. Сластьонін, М. Сметанський, В. Сухомлинський, Н. Тализіна та ін., які розглядають професійне становлення як цілеспрямований процес, що забезпечує особистісний і професійний розвиток фахівця, що відбувається впродовж усього життя й має на меті набуття важливих професійно-особистісних якостей, необхідних для обраної спеціальності.

На підставі аналізу наукового фонду нами докладно розкрито сутність поняття «професійне становлення майбутнього вчителя», визначено етапи та складники цього процесу в монографії «Теорія та методика професійно-педагогічної підготовки освітянських кадрів: акмеологічні аспекти» ${ }^{2}$. Професійне становлення майбутніх учителів потрактовано як складний, багатофакторний педагогічний процес, що характеризується їхнім особистісним і професійним розвитком, зростанням і саморозвитком, результатом якого $\epsilon$ професіоналізм, що розуміється як якісна характеристика педагога, яка відображає високу професійну кваліфікацію та компетентність, розмаїття ефективних навичок i вмінь, володіння сучасними алгоритмами та способами розв'язання педагогічних завдань, що дає змогу здійснювати професійну діяльність з високою продуктивністю.

На нашу думку, важливу роль у професійній підготовці майбутніх учителів відіграють методологічні підходи, застосування яких в освітньому процесі педагогічних вишів сприяє їхньому успішному професійному становленню. Розглянемо деякі з них.

${ }^{1}$ Савченко О.Я. Ціннісні орієнтації шкільної освіти. Філософія освіти XXI століття: проблеми і перспективи: збірник наукових праць за матеріалами методологічного семінару, м. Київ, 22 листопада 2000 р. Київ : Знання, 2000. Вип. 3. С. 8.

${ }^{2}$ Курлянд 3.Н., Осипова Т.Ю., Галіцан О.А. Концепція мультиплікативності як акмеологічна координата професійного становлення майбутніх учителів в освітньому середовищі ВНЗ. Теорія та методика професійно-педагогічної підготовки освітянських кадрів: акмеологічні аспекти : монографія / керівн. авт. кол. Н.В. Гузій. Київ : Вид-во НПУ імені М.П. Драгоманова, 2018. С. 123-176. 


\section{1. Культурологічний та аксіологічний підходи до професійного становлення майбутніх учителів в умовах університетської освіти}

\section{1. Культурологічний підхід}

Варто зазначити, що проблема культурологічного підходу постійно перебуває в полі зору науковців. Так, концептуальні положення й принципи культурологічного підходу в освіті розглядали філософи (М. Бахтін, В. Біблер, І. Берлянд, І. Зязюн, В. Кремень, В. Литовський, М. Михальченко та ін.), психологи (Г. Балл, І. Бех, Л. Виготський, 3. Карпенко, О. Кокун, О. Лурія, О. Леонтьєв, В. Мєдінцев та ін.), педагоги (І. Балхарова, І. Богданова, В. Гура, І. Ісаєв, Е. Карпова, О. Картавих, І. Колмолгорова, А. Погодіна, Л. Руденко та ін.).

У довідникових джерелах культурологічний підхід тлумачиться як конкретно-наукова методологія пізнання й перетворення педагогічної реальності, основою якої є аксіологія; бачення освіти через призму поняття культури, тобто розуміння ії як культурного процесу, що відбувається в культуровідповідному середовищі, усі компоненти якого наповнені людськими смислами і слугують людині, котра вільно проявляе свою індивідуальність, здатність до культурного саморозвитку й самовизначення у світі культурних цінностей ${ }^{3}$.

Культурологічний підхід передбачає розгляд людини, розуміння та пояснення іiі свідомості й індивідуальності в контексті чи площині феномена культури. За логікою зазначеного підходу, різні аспекти сутності людини як суб'єкта культури, а саме свідомість, самосвідомість, духовність, моральність, творчість, розуміються як грані цілісної культурної людини ${ }^{4}$.

За твердженням I. Ісаєва, культурологічний підхід до досліджень педагогічних проблем здійснюється в контексті загальнофілософського розуміння культури, що розглядається на рівні буденної й теоретичної свідомості. При цьому, наголошує автор, у буденній свідомості культура представлена неоднозначно: з одного боку, вона розуміється як дещо нормативне, задане як взірець, на який повинні рівнятися представники конкретного суспільства чи професійної групи; 3 іншого - ототожнюється 3 освіченістю, інтелігентністю людини; 3 третього - пов'язується 3 характеристикою місця й способу життя людини ${ }^{5}$ I хоча I. Ісаєв акцентує на дослідженнях педагогічних

${ }^{3}$ Культурологический подход. Мир словарей : экономический словарь. URL: http://mirslovarei.com/content_eco/kulturologicheskij-podxod-32415.htm.

4 Ху Дихуа. Формирование поликультурной компетентности иностранных студентов в условиях профессиональной подготовки: дисс. ... канд. пед. наук: 13.00.04. Одесса, 2013. С. 27.

5 Исаев И.Ф. Профессионально-педагогическая культура преподавателя : учебное пособие для студ. высш. учеб. завед. Москва : Академия, 2002. С. 7. 
проблем загалом, на нашу думку, такий підхід є важливим у процесі професійної підготовки майбутніх учителів, тобто їхнього професійного становлення в умовах університетської освіти.

Позитивним у контексті дослідження уважаємо й твердження Ю. Бойчука, що культурологічний підхід дає змогу розглядати професійне становлення майбутнього фахівця в процесі взаємодії духовної та матеріальної культури, засвоєння ним загальнолюдської й національної культури, усвідомлення й самореалізації культурних потреб, інтересів і здібностей. Основоположною ідеєю означеного підходу, на думку дослідника, є людиноцентризм, тобто визнання цінності людини як особистості, визнання іiі прав на вільний розвиток $\mathrm{i}$ виявлення власних здібностей, зорієнтованість на самоцінність i біопсихосоціальну унікальність людини ${ }^{6}$.

Аналогічну думку висловлюють й інші дослідники (Л. Подимова, В. Сластьонін), які зазначають, що культурологічний підхід передбачає формування морально-етичної культури особистості фахівця, hото moralis - людини із совістю, котра вміє розрізняти добро і зло, володіє високими стійкими моральними орієнтирами. Культура особистості фахівця «є упорядкованою сукупністю загальнолюдських ідей, ціннісних орієнтацій і якостей особистості, універсальних способів пізнання та гуманістичних технологій професійної діяльності» ${ }^{7}$.

У професійній підготовці майбутніх фахівців, зазначає В. Гура, сутність культурологічного підходу полягає в тому, що в центрі уваги має перебувати людина як суб'єкт культури, а освітнє середовище закладу вищої освіти має розбудовуватися передусім як культурне середовище. У зв'язку 3 цим культурологічний підхід ним по трактований як «таке бачення людини крізь призму понять культури, яке дає змогу розглядати людину в освітній діяльності як вільну, активну індивідуальність, здатну до самодетермінації в горизонті особистості в результаті спілкування 3 іншими особистостями, культурами як у межах сьогоднішнього життєвого світу особистості (Малий час культури), так і в інших епохах (Великий час культури)» ${ }^{8}$. Інакше кажучи, в аспекті культурологічного підходу майбутній

6 Бойчук Ю.Д. Культурологічний і аксіологічний підходи до формування еколого-валеологічної культури студентів вищих педагогічних навчальних закладів. Вісник НТУУ, КПІ. Серія "Філософія. Психологія. Педагогіка». 2009. № 3. C. $121-124$.

7 Сластенин В.А., Подымова Л.С. Педагогика: инновационная деятельность. Москва : Магистр, 1997. С. 64.

${ }^{8}$ Гура В.В. Культурологический поход как теоретико-методологическая основа гуманизации информационных технологий обучения : автореф. дисс. ... канд пед. наук : 13.00.01. Ростов-на-Дону, 1994. С. 11. 
фахівець розглядається як вільна людина, яка через буття в культурі може самовизначатися як особистість.

Інтерпретуючи положення культурологічного підходу В. Гури в контексті професійної підготовки майбутніх учителів, сформулюємо їх так: а) перехід від схеми «студент - навчальні засоби - знання» до схеми «студент - культура - навчальні засоби - знання»; б) контекстна зумовленість навчального матеріалу та багаторівневість діалогових відносин усередині навчального тексту; в) уведення як ланки системи навчання підсистеми психологічної підтримки 3 метою підтримки діалогових стосунків; г) задоволення інформаційно-пізнавальних потреб студентів і їх стимулювання 9 .

Досліджуючи сутність культурологічного підходу до формування педагогічної культури вчителя, що $\epsilon$ важливим в аспекті започаткованого дослідження, I. Колмогорова визначає його як «сукупність теоретико-методологічних положень та організаційнопедагогічних заходів, спрямованих на створення умов для освоєння й трансляції педагогічних цінностей і технологій, котрі забезпечують творчу самореалізацію особистості вчителя в професійній діяльності» ${ }^{10}$. I продовжує, що зв'язок такого підходу 3 культурою акцентує насамперед на професійних цінностях i самореалізації вчителя в професійній діяльності.

Додамо до цього, що в процесі професійної підготовки майбутні вчителі засвоюють традиції певної культури подальшої професійної діяльності, опановують систему соціальних норм, які ставляться до педагогічних працівників.

Цілком погоджуючись із вищевикладеним, зазначимо, що в умовах університетської освіти можна говорити й про необхідність культурологічного підходу до професійного становлення майбутніх учителів у полікультурному середовищі, зважаючи на те що в українських вишах здобувають професійну освіту багато іноземних студентів і те, що в закладах загальної освіти також навчаються представники різних культур, оскільки Україна є багатонаціональною країною.

Відповідно до цього, одним із головних принципів культурологічного підходу до професійного становлення майбутніх учителів $є$ принцип діалогу культур, оскільки культура має діалогічну природу, тобто кожна окрема культура існує у формі низки діалогів 3

${ }^{9}$ Гура В.В. Культурологический поход как теоретико-методологическая основа гуманизации информационных технологий обучения : автореф. дис. ... канд пед. наук : 13.00.01. Ростов-на-Дону, 1994. С. 11.

10 Колмогорова И.В. Культурологический подход к формированию педагогической культуры учителя. Известия Уральского государственного университета. 2008. № 60. С. 166. 
іншими культурами. Отже, особистість, якщо розглядати іiі як утілення або буття культури в людському індивіді, також є багатошаровою або, якщо говорити в термінах концепції діалогу культур, у ній звучать різні самостійні голоси різних культур, утворюючи поліфонію діалогу ${ }^{11}$.

3 огляду на це, в освітньому процесі закладу вищої педагогічної освіти необхідно враховувати національні й релігійні особливості представників різних культур, а також знайомити їх з українською культурою і культурою інших країн, що, на нашу думку, сприятиме збагаченню духовної культури студентів, усвідомленню розмаїття культур у світі, запобіганню виникнення міжкультурних конфліктних ситуацій.

3 позиції культурологічного підходу, за О. Картавих, діяльність викладача у вищій школі передбачає єдність змісту, форм, засобів i методів освіти, спрямованих на стимулювання духовного розвитку майбутніх фахівців. Основними завданнями цього процесу $\epsilon$ формування професійно-педагогічної культури, формування високих культурних потреб та інтересу до вдосконалення культури спілкування, визначення свого місця в діалозі культур, а також розвиток культурного самопізнання ${ }^{12}$.

Отже, культурологічний підхід до професійного становлення в умовах університетської освіти грунтується на єдності змісту, форм, засобів і методів професійної освіти, що забезпечують культурний i духовний розвиток майбутніх учителів, розвиток культурного самопізнання, спосіб самореалізації, самоствердження й саморозвитку в майбутній педагогічній діяльності, сприяють формуванню професійно-педагогічної культури й культури спілкування, професійно значущих якостей, усвідомленню свого місця в діалозі культур, розумінню норм професійної діяльності, виробленню професійної поведінки, що не суперечить вимогам суспільства до особистості вчителя.

Культурологічний підхід до професійного становлення майбутніх учителів в умовах університетської освіти тісно пов'язаний 3 аксіологічним підходом, оскільки система цінностей у широкому розумінні є внутрішнім стрижнем культури, при цьому засвоєння i створення нових цінностей можливе лише в культурному середовищі й завдяки духовній активності людини, іiї взаємодії з довколишнім світом

${ }^{11}$ Балл Г.О., Мєдінцев В.О. Особистість як індивідуальний модус культури і як інтегративна якість особи. Горизонти освіти. 2011. № 3. С. 7-14.

${ }_{12}$ Картавих О.В. Аксіологічні основи формування загальної культури студентів вищих технічних навчальних закладів : автореф. дис. ... канд. пед. наук : 13.00.04. Харків, 2002. С. 12. 
i собою, коли «система ціннісних уявлень культури має бути інтегрована в смисловий простір професіонала» ${ }^{13}$.

\section{2. Аксіологічний підхід}

Теоретичні засади аксіологічного підходу в освітньому процесі були предметом наукових досліджень таких науковців, як В. Андрєєва, I. Артюхов, Н. Астахова, В. Бігун, I. Бех, С. Бондаревська, Т. Бутківська, В. Василенко, В. Гринькова, Б. Додонов, О. Дробницький, А. Здравомислов, I. Ісаєв, В. Кремінь, В. Крижко, Д. Леонтьєв, В. Ликова, В. Момов, В. Огнев’юк, В. Ольшанський, В. Сластьонін, О. Сухомлинська, В. Тугарінов, М. Тітма, Л. Хомич, Н. Щуркова, В. Ядов та ін. Дослідники зазначають, що аксіологічний підхід у процесі професійно-педагогічної підготовки проходить наскрізною лінією через усі його компоненти, а найважливішим в опануванні педагогічних цінностей є суб'єкт-особистісна активність майбутнього педагога, яка виявляється в тому, що він має проживати, переживати, захищати і стверджувати їх у подальшій соціально корисній і продуктивній творчій діяльності ${ }^{14}$.

Професійне становлення майбутнього фахівця, за Т. Садовою, неможливе без формування світоглядних орієнтирів i ціннісних орієнтацій, його загальної морально-духовної культури. Отже, аксіологічний підхід призначений реалізовувати в практичній діяльності й формувати в людини системи загальнолюдських i професійних цінностей, що визначають іiї ставлення до світу, до своєї діяльності, до самої себе як людини та професіонала ${ }^{15}$.

На думку Н. Мойсеюк, методологічною основою змісту аксіологічного підходу є система аксіологічних принципів, що дають змогу різним наукам і течіям, об'єднаним гуманістичною орієнтацією, здійснювати спільний пошук оптимальних рішень на підставі діалогу, а саме:

1) рівноправність усіх філософських поглядів у межах єдиної гуманістичної системи цінностей (за збереження різноманітності їх культурних та етнічних особливостей);

2) рівнозначність традицій i творчості, визнання необхідності вивчення й використання учінь минулого та можливості відкриття в теперішньому чи майбутньому;

3) екзистенційна рівність людей, соціокультурний прагматизм замість суперечок про підгрунтя цінностей;

13 Буякас Т.М. Ценностно-смысловая сфера профессионала. Мир психологии. 1997. № 3. C. 30.

14 Біла книга національної освіти України / Т.Ф. Алексеєнко, В.М. Аніщенко, Т.О. Балл та ін. ; за заг. ред. акад. В.Г. Кременя. Київ : Інформ системи, 2010. С. 272.

${ }^{15}$ Садова Т. Аксіологічний підхід у системі педагогічної методології. Дошкільна oсвima. 2010. № 1 (27). С. 63. 
4) діалог замість байдужості чи взаємозаперечення ${ }^{16}$.

Аксіологічний підхід посідає важливе місце в системі професійної освіти, оскільки в його межах відбувається формування в майбутніх фахівців системи загальнолюдських і професійних цінностей. Означений підхід пов'язаний з упровадженням в освітній процес різних ціннісних орієнтирів, що стосуються духовно-прагматичної структури ставлення студентів до самих себе й інших людей. При цьому аксіологічний підхід реалізується не як «презентація» системи цінностей, а як середовище, в умовах якого відбувається актуалізація визначених цінностей, засвоєння їх студентами.

3 позицій аксіологічного підходу, зазначає О. Єфімова, професійна освіта вирішує важливе завдання - розкриття цінностей як основних рушійних сил особистості, ii інтелектуального, морального, творчого потенціалу, оскільки є зв'язком між теорією і практикою, тобто $є$ ланкою між пізнавальним і практичним ставленням до світу ${ }^{17}$.

Аксіологічний підхід передбачає формування в майбутніх учителів загальнолюдських, національних $\mathrm{i}$ професійних цінностей. До універсальних загальнолюдських цінностей науковцями (С. Анісімов, М. Каган, А. Кир'якова, В. Сластьонін та ін.) зараховано:

- життя в усіх його проявах; людину як найвищу цінність буття 3 комплексом гуманістичних якостей (любов, добро, спілкування, щастя, гідність тощо);

- пізнання та його компоненти (інформація, знання, культура, істина, засіб самовираження); красу, форми і способи іiі створення й прояви (мистецтво, творчість, прекрасне в природі, естетика праці та побуту);

- працю та іï аспекти (засіб існування й самовдосконалення, джерело пізнання та радості, основа творчості й можливості самореалізації, основа професіі);

- Батьківщину як умову існування особистості (форма вираження національної самосвідомості, умова дотримання соціальної справедливості, дотримання прав і свобод людини, гарантія безпеки і миру).

3 позиції аксіологічного підходу професійне становлення майбутніх учителів передбачає формування в них сукупності відносно стійких педагогічних цінностей, ціннісного ставлення до педагогічної діяльності, вироблення в студентів індивідуального стилю діяльності, прагнення до самовизначення, самоактуалізації й самореалізації.

${ }^{16}$ Мойсеюк Н.Є. Педагогіка: навчальний посібник. 5-те вид., доп. і перероб. Київ : Кондор, 2007. С. 213.

${ }^{17}$ Ефимова Е.М. Методы формирования социальной устойчивости личности в условиях высшего профессионального образования. Вестник МГОУ. Серия «Педагогика». 2012. № 3. С. 54. 
Науковцями (В. Андрєєва, . Додонов, I. Ісаєв, Д. Леонтьєв, В. Сластьонін, В. Ядов та ін.) аксіологічний підхід розглядається як методологічна основа процесу професійної підготовки майбутніх учителів у межах вивчення педагогічних дисциплін, що надає йому ціннісної спрямованості. Іншими дослідниками (І. Бех, О. Киричук, В. Сухомлинський та ін.) аксіологічний підхід визначається як інструмент відбору важливих професійних та особистісних цінностей педагогічної діяльності.

За В. Шаховим, реалізація аксіологічного підходу передбачає формування в майбутніх учителів сукупності відносно стійких цінностей педагогічної діяльності, оволодіння якими забезпечує трансформацію їх в особистісно значущі ${ }^{18}$.

Сучасні педагогічні цінності, наголошує В. Чайка, грунтуються на принципах демократизації, гуманізації, варіативності, диференціації та інтеграції, національного характеру, творчого підходу до освітньої діяльності тощо. Їх реалізація в освітньому процесі здійснюється, i, на нашу думку, це $\epsilon$ важливим у професійному становленні майбутніх учителів, через формування ціннісного ставлення до людини та визнання іiі розвитку провідним завданням освіти й виховання, забезпечення можливостей особистості щодо самовизначення, самоорганізації й самореалізації ${ }^{19}$.

Аксіологічний підхід у психолого-педагогічній підготовці майбутніх учителів, за Г. Мелекесовим, надає ціннісної орієнтації розв'язанню різноманітних соціально-педагогічних проблем, дає змогу систематизувати об'єктивні знання про соціальну та педагогічну дійсність. При цьому психологічна наука виявляє механізми опанування цінностей свідомістю, а педагогічна наука - засвоєння цінностей учнями в організованій педагогом ціннісно-орієнтаційній діяльності ${ }^{20}$.

3 огляду на зазначене, сформованість ціннісних орієнтацій, на думку науковця, визначає аксіологічний потенціал особистості майбутнього вчителя, що розглядається як багаторівневе інтегративне динамічне новоутворення, яке характеризується наявністю усталеної ієрархії ціннісних орієнтацій, що визначають характер його майбутньої професійної діяльності, прагнення й готовність до трансляції цінностей

18 Шахов В.І. Теоретико-методологічні основи базової педагогічної освіти майбутніх учителів : автореф. дис. ... докт. пед. наук : 13.00.04. Тернопіль, 2008. C. 5 .

19 Чайка В.М. Підготовка майбутнього вчителя до саморегуляції педагогічної діяльності : монографія / за ред. Г.В. Терещука. Тернопіль : ТНПУ, 2006. С. 26.

${ }^{20}$ Мелекесов Г.А. Развитие аксиологического потенциала личности будущего учителя : дисс. ... докт. пед. наук : 13.00.01. Оренбург, 2003. С. 59. 
культури (соціуму, освіти) в життєдіяльність школи, до забезпечення процесу залучення школярів до цінностей. Розвиток аксіологічного потенціалу особистості майбутнього вчителя, продовжує дослідник, передбачає якісні зміни в ціннісному ставленні до педагогічної діяльності (формування цілісного та ціннісного образу педагогічного світу, побудованого на взаємозв'язку аксіології й інноватики), до самого себе (становлення образа Я-педагог), до майбутньої педагогічної діяльності (проектування образу педагогічної діяльності) ${ }^{21}$.

Отже, аксіологічний підхід $є$ важливим у процесі професійного становлення майбутніх учителів, що передбачає формування в них системи ціннісного ставлення до педагогічної діяльності, педагогічних цінностей, ціннісних орієнтацій, усвідомлення людини як цінності і створює підгрунтя для формування відповідних цінностей в учнів у подальшій професійній діяльності.

\section{2. Особистісно-діяльнісний і компетентнісний підходи до професійного становлення майбутніх учителів \\ в умовах університетської освіти}

\section{1. Особистісно-діяльнісний підхід}

Основним положенням означеного методологічного підходу $\epsilon$ визнання провідної ролі діяльності в процесі професійної підготовки майбутніх фахівців. Сутність особистісно-діяльнісного підходу в освіті була предметом наукових досліджень І. Беха, Є. Бондаревської, Б. Долинського Е. Зеєра， І. Зимньої， Г. Китайгородської， Г. Микитюк Л. Мітіної, О. Пєхоти, В. Рибалки, А. Хуторського, І. Якиманської та інших дослідників, які цілком слушно стверджують, що професійна підготовка має розглядатися в єдності особистісного й діяльнісного складників. Особистісний складник передбачає, що в центрі навчання знаходиться індивід із його мотивами, цілями, індивідуальними особливостями, який потребує визнання унікальності його особистості, його інтелектуальної й моральної свободи, права на повагу. Діяльнісний складник відображає взаємодію викладачів і студентів, передбачає опанування майбутніми фахівцями способів i засобів майбутньої професійної діяльності, створює умови для активної позиції суб'єкта діяльності, завдяки чому відбувається засвоєння ним певного професійного досвіду.

Особистісно-діяльнісний підхід, на думку В. Бєлікова, спрямований на забезпечення розвитку особистості через організацію ii діяльності; єдність взаємозв'язку та взаємопереходу особистісного й предметного

${ }^{21}$ Мелекесов Г.А. Развитие аксиологического потенциала личности будущего учителя : дисс. ... докт. пед. наук : 13.00.01. Оренбург, 2003. С. 263. 
аспектів діяльності; підпорядкування освіти на кожному рівні розвитку особистості iii інтересам і здібностям; формування уявлення про освітньо-пізнавальну діяльність як особистісно значущу ${ }^{22}$.

Важливим в аспекті започаткованого дослідження $\epsilon$ твердження Б. Долинського, що суб'єкту притаманні свідомість і самосвідомість, він характеризується здібністю до саморегуляції, самовизначення, самореалізації наявних знань і вмінь відповідно до поставленої мети й завдань обраної професії чи його життєвого шляху. Самореалізація та самовизначення суб'єкта можливі тільки в процесі діяльності, у ході якої виявляються психічні якості (потреби, переживання, задуми, подолання перешкод тощо), що дають змогу досягти поставленої мети. Тому саме діяльність є важливою формою вияву активності суб'єкта, провідним способом його існування, життєдіяльності ${ }^{23}$.

В основу особистісно-діяльнісного підходу покладено особистісний принцип діяльності, положення про діяльнісну природу людини крізь призму ідеї суб'єктності, характеристику діяльності як прояву активності суб'єкта в системі його суспільних відносин (за С. Рубінштейном) $)^{24}$.

У процесі професійного становлення майбутніх учителів особистіснодіяльнісний підхід відіграє значну роль, оскільки професійна діяльність учителя грунтується насамперед на організації взаємодії з учнями, тому під час професійної підготовки студенти повинні не тільки засвоїти теоретичні психолого-педагогічні та фахові знання, а й набути практичних умінь $\mathrm{i}$ навичок їх застосування в ході вирішення теоретичних i практичних професійних завдань, тобто вміння використовувати здобуті знання й уміння в безпосередній професійній діяльності. Отже, професійна підготовка майбутніх учителів повинна бути спрямована на формування їхніх особистісних і професійно-значущих якостей, здатності здійснювати різноманітні види діяльності в освітньому процесі, спрямованих на навчання й виховання учнів.

На необхідності запровадження в освітній процес особистіснодіяльнісного підходу наголошують такі вчені, як І. Бех, Л. Виготський, П. Гальперін, В. Давидов, Д. Ельконіна, О. Леонтьєв, Н. Тализіна, В. Шадриков та інші науковці, які зазначають, що розвиток особистості

${ }^{22}$ Беликов В.А. Образование. Деятельность. Личность : монография Москва : Академия естествознания, 2010. 340 c. URL: http://www.rae.ru/monographs/76.

${ }^{23}$ Долинський Б.Т. Теоретико-методичні засади підготовки майбутніх учителів до формування здоров'язбережувальних навичок і вмінь у молодших школярів у навчально-виховній діяльності : дис. ... докт. пед. наук : 13.00.04. Одеса, 2011. C. $61-62$.

${ }^{24}$ Рубинштейн С.Л. Основы общей психологии. Санкт-Петербург : Питер Ком, 1999. C. 492. 
забезпечується формуванням універсальних навчальних дій, які є основою освітнього процесу. 3 огляду на зазначене, під час навчання в закладах вищої педагогічної освіти основна увага викладачів повинна бути спрямована не на накопичення певного обсягу знань, умінь і навичок, а на становлення особистості майбутнього вчителя, ii професійного становлення в процесі навчання як діяльності. Інакше кажучи, має вибудовуватися інша система взаємин у діаді «викладач - студент», у якій студент $є$ рівноправним активним учасником освітнього процесу.

Характерологічними рисами особистісно-діяльнісного підходу дослідниками (В. Андрєєв， В. Серіков， В. Сластьонін， І. Якиманська й ін.) визначено такі: у центрі процесу перебуває особистість студента зі своїми неповторними індивідуальними властивостями (а також національними й релігійними особливостями його країни); організація процесу навчання на підставі суб'єкт-суб'єктних відносин, педагогічної співпраці під час вирішення осітньо-пізнавальних завдань; надання кожному суб'єктові навчального процесу можливості індивідуального освоєння й перетворення довколишньої дійсності, використовуючи особистісний досвід, особистісно значущі цінності, систему позитивних мотивів ${ }^{25}$.

За І. Зимньою, особистісно-діяльнісний підхід забезпечує «безпеку особистісного прояву» майбутнього фахівця в усіх ситуаціях навчання, створення умов для його особистісного зростання й самоактуалізації; формує активність самого студента, його готовність до певного виду діяльності, до розв'язання проблемних завдань на умовах рівнопартнерських, довірливих суб'єкт-суб'єктних відносин із викладачем; із позиції студента передбачає єдність його зовнішніх $\mathrm{i}$ внутрішніх мотивів, де зовнішнім є мотив досягнення, а внутрішнім пізнавальний мотив; означає прийняття навчального завдання й задоволення від іiі вирішення в співробітництві з іншими студентами. Саме це, на думку науковця, є основою розвитку не тільки почуття компетентності й афіліації як компонентів власної гідності, а й значною мірою почуття впевненості в собі як передумови самоактуалізації, тобто розвиток не тільки професійної компетентності студента, а і його особистості загалом ${ }^{26}$.

Отже, особистісно-діяльнісний підхід у професійному навчанні має спиратися на такі положення: розвивати пізнавальний мотив студентів (прагнення до пошуку нової інформації); визначати конкретну навчальну мету (що потрібно засвоїти для виконання завдання); залучати студентів до

${ }^{25}$ Осипова Т.Ю. Теоретико-методичні засади підготовки майбутніх учителів до педагогічного наставництва : дис. ... докт. пед. наук : 13.00.04. Одеса, 2016. С. 127.

26 Зимняя И.А. Педагогическая психология. Москва : Логос, 2000. 384 с. С. 115. 
дій, які сприяють засвоєнню нових знань і формуванню відповідних умінь; виконувати дії, що передбачають застосування набутих знань і вмінь; формувати вміння контролювати дії; включати завдання 3 вирішення життєвих та актуальних професійних ситуацій ${ }^{27}$.

Особистісно-діяльнісний підхід, наголошує Б. Долинський, висуває необхідність у сучасних закладах вищої педагогічної освіти змінити позицію викладача-інформатора як джерела знань, контролера на позицію фасилітатора; створення таких освітніх ситуацій, які б сприяли розкріпаченню студентів; створення умов для розвитку гармонійної морально досконалої, соціально активної особистості шляхом активізації іiі внутрішніх резервів, професійно компетентної особистості, здатної до подальшого саморозвитку й самовизначення ${ }^{28}$.

Отже, особистісно-діяльнісний підхід у професійному становленні майбутніх учителів спрямований на пізнання, прояв $\mathrm{i}$ розвиток особистістю своїх можливостей, досягнення поставлених цілей у вирішенні значущих для неї проблем, що дає ій змогу максимально повно реалізувати свій творчий потенціал, допомагає студентам зрозуміти сутність педагогічної діяльності, закономірності цього процесу, визначити зв'язок між теоретичною та практичною професійною підготовкою, передбачає необхідність формування в студентів активної позиції, коли майбутні вчителі $\epsilon$ активними суб'єктами пізнавальної й творчої діяльності, спрямованої на засвоєння навчального матеріалу та набуття вмінь використовувати їх $\mathrm{y}$ різноманітних ситуаціях, а також на розвиток особистісних якостей ${ }^{29}$.

Підсумовуючи, доходимо висновку, що застосування в освітньому процесі закладів вищої педагогічної освіти особистісно-діяльнісного підходу спрямовано на усвідомлення й розуміння майбутніми вчителями сутності педагогічної діяльності, забезпечення єдності теоретичної та практичної професійної підготовки, створення необхідних умов для активізації пізнавальної й творчої діяльності студентів, що сприятиме засвоєнню професійних знань і розвитку практичних умінь їх використання в різних видах діяльності, а також розвитку їхніх особистісно-значущих якостей.

27 Кононенко I.А. Професійне становлення майбутніх учителів філологічних спеціальностей у системі вищої освіти Франції : дис. ... канд. пед. наук : 13.00.04. Переяслав-Хмельницький, 2017. С. 28.

28 Долинський Б.Т. Теоретико-методичні засади підготовки майбутніх учителів до формування здоров'язбережувальних навичок і вмінь у молодших школярів у навчально-виховній діяльності : дис. ... докт. пед. наук : 13.00.04. Одеса, 2011. С. 65.

${ }^{29}$ Осипова Т.Ю. Теоретико-методичні засади підготовки майбутніх учителів до педагогічного наставництва : дис. ... докт. пед. наук : 13.00.04. Одеса, 2016. С. 121. 
Зважаючи на те що предметом дослідження $є$ професійне становлення майбутніх учителів в умовах університетської освіти, неможливо не акцентувати на необхідності побудови освітнього процесу в закладі вищої педагогічної освіти на засадах компетентнісного підходу.

\section{2. Компетентнісний підхід}

Варто зазначити, що в сучасних наукових дослідженнях зарубіжних (Дж. Берч, Дж. Каллаган, А. Кларк, Д. МакКлелланд, Дж. Равен, C. Спенсер, Г.-Х. Хофманн, А. Шелтен, Р. Уайт), російських

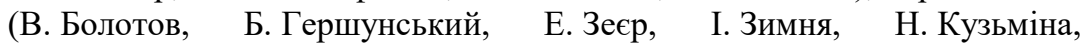
А. Маркова, В. Сластьонін, Ю. Татур, А. Хуторський та ін.) та українських (В. Баркасі, П. Бачинський, І. Бех, Н. Бібік, О. Бондаренко, І. Босак, Л. Ващенко,А. Гуржій І. Драч, О. Дубасенюк, Н. Дворнікова, I. Єрмаков, Л. Карпова, М. Левківський, О. Локшина, А. Маркова, О. Овчарук, Л. Паращенко, Л. Петровська, О. Пометун, О. Савченко, C. Трубачева та ін.) науковців значна увага приділяється компетентнісному підходу в освіті, вони зазначають, що компетентність характеризується здатністю до практичної реалізації сукупності знань, умінь та особистісних якостей у вирішенні конкретних проблем професійної діяльності.

Побудова освітнього процесу в закладах вищої освіти на засадах компетентнісного підходу, за визначенням Л. Руденко, передбачає спрямованість на формування професійної компетентності майбутніх фахівців як інтегрованої характеристики, що охоплює знання, уміння, навички, особистісні якості, досвід діяльності й моделі поведінки, які мають опанувати студенти в процесі професійної підготовки для подальшої успішної діяльності. Формування професійної компетентності, стверджує дослідниця, і з цим не можна не погодитися, не лише забезпечить якісне вирішення професійних завдань, а й сприятиме самоорганізації особистості та діяльності фахівців, виявленню й розвитку їхнього творчого потенціалу ${ }^{30}$.

Суголосну думку виголошує Н. Циган, акцентуючи на тому, що професійна компетентність $є$ сукупністю професійних якостей, знань, умінь і навичок, необхідних для виконання професійної діяльності. Науковець зазначає, що в процесі професійного становлення студенти повинні опанувати компетентність сприйняття (здатність до спостереження, аналізу тощо), компетентність взаємодії (установлення взаємин і здійснення діяльності - аналіз ситуації, розуміння випадку,

${ }^{30}$ Руденко Л.А. Формування комунікативної культури майбутніх фахівців сфери обслуговування у професійно-технічних навчальних закладах : монографія. Львів : Піраміда, 2015. С. 77. 
обмін інформацією, пояснення, аналіз із подальшим висновком, самостійне вирішення проблеми), комунікативну компетентність (установлення контакту, взаємодії, налагодження довірливих, доброзичливих відносин), рефлексивну компетентність (реконструкція процесу надання допомоги, мета якої - переконатися в правильності зробленого або того, що можна було зробити) $)^{31}$.

Отже, професійна компетентність інтегрує теоретичну та практичну готовність особистості до діяльності й характеризує ії професіоналізм. 3 огляду на зазначене, компетентнісний підхід у професійній освіті, на думку дослідників (В. Байденко, Дж. Ван Занворт, Г.-Х. Хофманн, Ф. Шарипов та ін.), спрямований на те, щоб перейти від орієнтації на відтворення знань до їх застосування; зробити пріоритетними міждисциплінарно-інтегровані вимоги до результату освітнього процесу; більш тісно пов'язати цілі навчання 3 конкретними знаннями, уміннями, навичками, необхідними для розв'язання практичних завдань професійної діяльності; орієнтувати навчальну активність студентів на широке розмаїття професійних і життєвих ситуацій. У такий спосіб, доходить висновку Л. Марцева, застосування компетентнісного підходу забезпечує оптимізацію підготовки майбутніх фахівців шляхом створення найбільш раціональних технологій навчання, спрямованих на скорочення часу й зусиль суб'єктів освітнього процесу для одержання необхідної компетентності ${ }^{32}$.

3 огляду на це, компетентнісний підхід спрямовано насамперед на перехід у навчанні «3 процесу на результат у діяльнісному вимірі, забезпечення спроможності випускника відповідати новим запитам ринку, мати відповідний потенціал для практичного розв'язання життєвих проблем, пошуку свого «Я» у професії» (за Н. Бібік) $)^{33}$.

Щодо професійного становлення майбутніх учителів в умовах університетської освіти, то організація освітнього процесу, що грунтується на компетентнісному підході, крім набуття теоретичних професійних знань, дає можливість підсилити саме практичну спрямованість професійної підготовки студентів, сприяє набуттю певного професійного досвіду під час проходження різних педагогічних практик, де вони мають змогу реалізувати отримані

31 Циган Н.В. Особливості формування професійної компетентності при підготовці фахівців для різних типів соціальних закладів. Збірник наукових праць Хмельницького інституту соиіальних технологій Університету «Украӥна». 2017. № 13. C. 71-75. URL: http://nbuv.gov.ua/UJRN/Znpkhist_2017_13_19.

32 Марцева Л.А. Професійна підготовка молодших спеціалістів радіотехнічного профілю в технічних коледжах : монографія. Вінниця : Фенікс Медіа, 2015. С. 50.

33 Компетентнісний підхід у сучасній освіті: світовий досвід та українські перспективи: Бібліотека з освітньої політики / під заг. ред. О.В. Овчарук. Київ : K.I.C., 2004. C. 47. 
психолого-педагогічні та фахові знання й уміння під час вирішення професійних ситуацій, а також сприяе розвитку в студентів особистісних i професійно значущих якостей, необхідних для самостійного виконання подальшої професійної діяльності.

Основними ознаками компетентнісного підходу є загальносоціальна й особистісна значущість знань, умінь, навичок, якостей і способів продуктивної діяльності, що формуються під час здобуття освіти; формування компетентностей як сукупності смислових орієнтацій, що базуються на грунті національної та загальнолюдської культури; створення ситуацій для комплексної перевірки вмінь практичного використання знань і набуття життєвого досвіду; інтегративність характеристики особистості, що пов'язана 3 iї здатністю вдосконалювати набуті знання, уміння та способи діяльності в процесі соціалізації й накопичення досвіду життєдіяльності ${ }^{34}$.

Зважаючи на характер та особливості педагогічної діяльності, О. Дубасенюк виокремлює три групи ключових компетентностей: 1) соціальні (пов'язані з оточенням, життям суспільства соціальною діяльністю особистості педагога), 2) мотиваційні (пов'язані з внутрішньою мотивацією, інтересами, індивідуальним вибором особистості педагога; 3) функціональні (пов'язані зі сферою знань, умінь і навичок оперувати науковими знаннями та фактичним матеріалом) ${ }^{35}$.

Компетентнісний підхід до навчання, на думку Л. Марцевої, вимагає певної послідовності у вивченні навчальних дисциплін:

- перший блок навчальних дисциплін орієнтовано на розвиток у студентів ключових компетентностей майбутньої професійної діяльності;

- другий блок орієнтує на «занурення» студента в професійні завдання, засвоєння способів їх розв'язання, які сприяють виробленню його базової компетентності на основі сформованих ключових компетентностей;

- третій блок навчальних дисциплін спрямовано на формування спеціальної компетентності майбутніх фахівців на основі базової компетентності ${ }^{36}$.

3 огляду на вищезазначене, можна стверджувати, що організація освітнього процесу в межах компететнісного підходу передбачає інтеграцію

34 Исаева Т. Преподаватель как субъект качества образования. Bысшее образование в России. 2003. № 2. С. 17-23.

35 Дубасенюк О.А. Компетентнісний підхід у професійній підготовці вчителя. Формування естетичної компетентності особистості засобами народознавства : збірник наукових праць молодих дослідників / за заг. ред. О.С. Березюк, Л.О. Глазунової. Житомир : Вид-во ЖДУ ім. І. Франка, 2010. С. 4.

36 Марцева Л.А. Реалізація компетентнісного підходу в професійній освіті. Компетентнісний підхід в освіті: теоретичні засади $і$ практика реалізаиії: матеріали методол. семінару, м. Київ, 3 квіт. 2014 р. Київ : Ін-т обдарованої дитини НАПН України, 2014. Ч. 2. С. 18-21. 
психолого-педагогічних i предметних (фахових) знань i ï практичну реалізацію в розв'язанні професійних завдань і педагогічних ситуацій, що максимально наближені до майбутньої професійної діяльності.

Отже, професійне становлення майбутніх учителів в умовах університетської освіти процесу на засадах компетентнісного підходу передбачає переорієнтацію з накопичення необхідних професійних знань $\mathrm{i}$ вмінь на здатність їх практичного використання у вирішенні педагогічних ситуацій, приймати рішення й нести відповідальність за їх реалізацію, прогнозувати ситуацію й власну педагогічну діяльність, планувати та контролювати педагогічні дії, усвідомлення й розуміння власного професійного «Я», сформованість педагогічних цінностей, позитивної мотивації до здійснення педагогічної діяльності й досягнення в ній успіху, налаштованість на професійний та особистісний саморозвиток, самовдосконалення й самореалізацію впродовж усього життя.

\section{ВИСНОВКИ}

Розглядаючи сутність професійного становлення майбутніх учителів в умовах університетської освіти, дійшли висновку, що важливу роль у цьому відіграє побудова освітнього процесу на засадах культурологічного, аксіологічного, особистісно-діяльнісного й компетентнісного підходів.

Визначено, що культурологічний підхід грунтується на єдності змісту, форм, засобів і методів професійної освіти, що забезпечують культурний i духовний розвиток майбутніх учителів, розвиток культурного самопізнання, спосіб самореалізації, самоствердження й саморозвитку в майбутній педагогічній діяльності, сприяють формуванню професійно-педагогічної культури й культури спілкування, професійно значущих якостей, усвідомленню свого місця в діалозі культур, розумінню норм професійної діяльності, виробленню професійної поведінки, що не суперечить вимогам суспільства до особистості вчителя.

Аксіологічний підхід передбачає формування в майбутніх учителів системи ціннісного ставлення до педагогічної діяльності, педагогічних цінностей, ціннісних орієнтацій, усвідомлення людини як цінності, створює підгрунтя для формування відповідних цінностей в учнів у подальшій професійній діяльності.

Особистісно-діяльнісний підхід спрямовано на усвідомлення й розуміння майбутніми вчителями сутності педагогічної діяльності, забезпечення єдності теоретичної та практичної професійної підготовки, створення необхідних умов для активізації пізнавальної й творчої діяльності студентів, що сприятиме засвоєнню професійних знань і розвитку практичних умінь їх використання в різних видах діяльності, а також розвитку їхніх особистісно-значущих якостей. 
Застосування компетентнісного підходу передбачає переорієнтацію 3 накопичення необхідних професійних знань і вмінь на здатність їх практичного використання у вирішенні педагогічних ситуацій, приймати рішення й нести відповідальність за їх реалізацію, прогнозувати ситуацію та власну педагогічну діяльність, планувати й контролювати педагогічні дії, усвідомлення й розуміння власного професійного «Я», сформованість педагогічних цінностей, позитивної мотивації до здійснення педагогічної діяльності й досягнення в ній успіху, налаштованість на професійний та особистісний саморозвиток, самовдосконалення й самореалізацію впродовж усього життя.

Установлено, що всі зазначені методологічні підходи $\epsilon$ взаємозумовленими та взаємопов'язаними, сприяють формуванню готовності майбутніх учителів до успішного виконання професійнопедагогічної діяльності.

\section{АНОТАЦІЯ}

У статті розглянуто сутність професійного становлення майбутніх учителів в умовах університетської освіти на сучасному етапі реформування вищої освіти в Україні. Професійне становлення майбутніх учителів розуміється як складний, багатофакторний педагогічний процес, що характеризується їхнім особистісним і професійним розвитком, зростанням i саморозвитком, результатом якого $\epsilon$ професіоналізм. Зазначено, що важливу роль у професійній підготовці майбутніх учителів відіграють методологічні підходи, застосування яких в освітньому процесі педагогічних вишів сприяе їхньому успішному професійному становленню. Визначено, що культурологічний підхід грунтується на єдності змісту, форм, засобів і методів професійної освіти, що забезпечують культурний i духовний розвиток майбутніх учителів, розвиток культурного самопізнання, спосіб самореалізації, самоствердження й саморозвитку в майбутній педагогічній діяльності. Аксіологічний підхід забезпечує формування в майбутніх учителів системи ціннісного ставлення до педагогічної діяльності, педагогічних цінностей, ціннісних орієнтацій, усвідомлення людини як цінності, створює підгрунтя для формування відповідних цінностей в учнів у подальшій професійній діяльності. Особистісно-діяльнісний підхід спрямовано на усвідомлення й розуміння майбутніми вчителями сутності педагогічної діяльності, забезпечення єдності теоретичної та практичної професійної підготовки, створення необхідних умов для активізації пізнавальної й творчої діяльності студентів. Застосування компетентнісного підходу передбачає переорієнтацію 3 накопичення необхідних професійних знань i вмінь на здатність їх практичного використання в подальшій професійній діяльності. Установлено, що всі 
зазначені методологічні підходи $€$ взаємозумовленими та взаємопов'язаними, сприяють формуванню готовності майбутніх учителів до успішного виконання професійно-педагогічної діяльності.

\section{ЛITЕРАТУРА}

1. Балл Г.О., Мєдінцев В.О. Особистість як індивідуальний модус культури і як інтегративна якість особи. Горизонти освіти. 2011. № 3. C. 7-14.

2. Беликов В.А. Образование. Деятельность. Личность : монография Москва : Академия естествознания, 2010. 340 c. URL: http://www.rae.ru/ monographs/76.

3. Біла книга національної освіти України / Т.Ф. Алексеєнко, В.М. Аніщенко, Т.О. Балл та ін. ; за заг. ред. акад. В.Г. Кременя. Київ : Інформ системи, 2010. $342 \mathrm{c}$.

4. Бойчук Ю.Д. Культурологічний i аксіологічний підходи до формування еколого-валеологічної культури студентів вищих педагогічних навчальних закладів. Вісник НТУУ, КПІ. Серія «Філософія. Психологія. Педагогіка». 2009. № 3. С. 121-124.

5. Буякас Т.М. Ценностно-смысловая сфера профессионала. Мир психологии. 1997. № 3. С. 26-32.

6. Гура В.В. Культурологический поход как теоретикометодологическая основа гуманизации информационных технологий обучения : автореф. дисс. ... канд пед. наук : 13.00.01. Ростов-на-Дону, 1994. $16 \mathrm{c}$.

7. Долинський Б.Т. Теоретико-методичні засади підготовки майбутніх учителів до формування здоров'язбережувальних навичок i вмінь у молодших школярів у навчально-виховній діяльності : дис. ... докт. пед. наук : 13.00.04. Одеса, 2011. 549 с.

8. Дубасенюк О.А. Компетентнісний підхід у професійній підготовці вчителя. Формування естетичної компетентності особистості засобами народознавства : збірник наукових праць молодих дослідників / за заг. ред. О.С. Березюк, Л.О. Глазунової. Житомир : Вид-во ЖДУ ім. І. Франка, 2010. С. 10-16.

9. Ефимова Е.М. Методы формирования социальной устойчивости личности в условиях высшего профессионального образования. Вестник МГОУ. Серия «Педагогика». 2012. № 3. С. 55-62.

10. Зимняя И.А. Педагогическая психология. Москва : Логос, 2000. $384 \mathrm{c}$.

11. Исаев И.Ф. Профессионально-педагогическая культура преподавателя : учебное пособие для студ. высш. учеб. завед. Москва : Академия, 2002. 208 с.

12. Исаева Т. Преподаватель как субъект качества образования. Высшее образование в России. 2003. № 2. С. 17-23. 
13. Картавих О.В. Аксіологічні основи формування загальної культури студентів вищих технічних навчальних закладів : автореф. дис. ... канд. пед. наук : 13.00.04. Харків, 2002. 20 с.

14. Колмогорова И.В. Культурологический подход к формированию педагогической культуры учителя. Известия Уральского государственного университета. 2008. № 60. С. 163-167.

15. Компетентнісний підхід у сучасній освіті: світовий досвід та українські перспективи: Бібліотека з освітньої політики / під заг. ред. О.В. Овчарук. Київ : К.І.С., 2004. 112 с.

16. Кононенко І.А. Професійне становлення майбутніх учителів філологічних спеціальностей у системі вищої освіти Франції : дис. ... канд. пед. наук : 13.00.04. Переяслав-Хмельницький, 2017. 319 с.

17. Культурологический поход. Мир словарей : экономический словарь. URL : http://mirslovarei.com/content_eco/kulturologicheskijpodxod-32415.html.

18. Курлянд 3.Н., Осипова Т.Ю., Галіцан О.А. Концепція мультиплікативності як акмеологічна координата професійного становлення майбутніх учителів в освітньому середовищі ВНЗ. Теорія та методика професійно-педагогічної підготовки освітянських кадрів: акмеологічні аспекти : монографія / керівн. авт. кол. Н.В. Гузій. Київ : Вид-во НПУ імені М.П. Драгоманова, 2018. С. 123-176.

19. Марцева Л.А. Професійна підготовка молодших спеціалістів радіотехнічного профілю в технічних коледжах : монографія. Вінниця : Фенікс Медіа, 2015. 420 c.

20. Марцева Л.А. Реалізація компетентнісного підходу в професійній освіті. Компетентнісний підхід в освіті: теоретичні засади і практика реалізації: матеріали методол. Семінару, м. Київ, 3 квіт. 2014 р. Київ : Ін-т обдарованої дитини НАПН України, 2014. Ч. 2. C. $17-22$.

21. Мелекесов Г.А. Развитие аксиологического потенциала личности будущего учителя : дисс. ... докт. пед. наук: 13.00.01. Оренбург, 2003. 419 с.

22. Мойсеюк Н.С. Педагогіка : навчальний посібник. 5-те вид., доп. і перероб. Київ : Кондор, 2007. 655 с.

23. Осипова Т.Ю. Теоретико-методичні засади підготовки майбутніх учителів до педагогічного наставництва : дис. ... докт. пед. наук : 13.00.04. Одеса, 2016. $501 \mathrm{c.}$

24. Рубинштейн С.Л. Основы общей психологии. Санкт-Петербург : Питер Ком, 1999. 720 с.

25. Руденко Л.А. Формування комунікативної культури майбутніх фахівців сфери обслуговування у професійно-технічних навчальних закладах : монографія. Львів : Піраміда, 2015. 343 с. 
26. Савченко О.Я. Ціннісні орієнтації шкільної освіти. Філософія освіти XXI століття: проблеми $i$ перспективи: збірник наукових праць за матеріалами методологічного семінару, Київ, 22 лист. 2000 р. Київ : Знання, 2000. Вип. 3. С. 23-27.

27. Садова Т. Аксіологічний підхід у системі педагогічної методології. Дошкільна освіта. 2010. № 1 (27). С. 63-69.

28. Сластенин В.А., Подымова Л.С. Педагогика: инновационная деятельность. Москва : Магистр, 1997. 224 с.

29. Ху Дихуа. Формирование поликультурной компетентности иностранных студентов в условиях профессиональной подготовки : дисс. ... канд. пед. наук : 13.00.04. Одесса, 2013. 228 с.

30. Циган Н.В. Особливості формування професійної компетентності при підготовці фахівців для різних типів соціальних закладів. Збірник наукових працьь Хмельнищького інституту соціальних технологій Університету «Україна». 2017. № 13. С. 71-75. URL: http://nbuv.gov.ua/UJRN/Znpkhist_2017_13_19.

31. Чайка В.М. Підготовка майбутнього вчителя до саморегуляції педагогічної діяльності : монографія / за ред. Г.В. Терещука. Тернопіль : ТНПУ, 2006. 275 с.

32. Шахов B.I. Теоретико-методологічні основи базової педагогічної освіти майбутніх учителів : автореф. дис. ... докт. пед. наук : 13.00.04. Тернопіль, 2008. 43 с.

\section{Information about the authors: \\ Osypova T. Yu.,} Doctor of Pedagogy,

Professor at the Department of Pedagogy South Ukrainian National Pedagogical University named after K. D. Ushynsky

26, Staroportofrankivska str., Odessa, Ukraine

ORCID ID: 0000-0002-6468-6545

Halitsan O. A.,

$\mathrm{PhD}$ (Candidate of Pedagogical Sciences), Associate Professor at the Department of Pedagogy

South Ukrainian National Pedagogical University named after K. D. Ushynsky

26, Staroportofrankivska str., Odesa, Ukraine

ORCID ID: 0000-0003-2542-649X 